UDC 658.6:004.738.5 (339.13)

JEL Classification: L81, M1, M31

\author{
Alona Natorina \\ PhD (Economics), Head of the International Economics \\ Accounting and Finance Department
} Academician Yuriy Bugay International Scientific and Technical University

(Kyiv, Ukraine)

\title{
DIGITAL BUSINESS IN UKRAINE: BACKGROUND AND RETROSPECT
}

Based on the analytical study results of the digital business background, it was found that in order to expand the boundaries of the target audience and increase the level of online buyers' satisfaction, retailers need to implement relevant marketing tools, optimize the work of the online store and mobile applications. According to the results of a comparative analysis of the Ukrainian DIY retailer's online stores activity, the driver-factors of digital business development are determined and interpreted, which are recommended to be used as part of the measures implementation to achieve the general goal. The retrospective analysis of the successful online experience of DIY retailers in Ukraine is conducted and the accents of the progressive and sustainable digital business development, which guarantee rapid scaling in the terms of intense competition and strengthen the competitive position of retailers, are suggested.

Key words: DIY retail, accents of the progressive and sustainable digital business development, driver-factors of the digital business development, online store, digital business.

\section{DOI: 10.15276/mdt.4.1.2020.1}

Statement of the problem in general form and it's connection with important scientific or practical tasks. Today's realities of business digitalization and the economy's digital transformation indicate dramatic changes for retailers on the Internet, namely, the vision rethinking, the business model construct reconfiguration and the business processes transformation which provides the positive online buyers' experience. The above emphasizes the importance of the correct interaction with online buyers in the context of ensuring the effective digital business.

Analysis of the latest research and publications, which initiated the solution of this problem and on which the author relies. Ukrainian scientists and economists in their scientific works and studies note the rapid development of digital business in the context of globalization, in particular: Goloborodko O., Gudz O., Kraus N., Lukianchenko O. [8], Oklander M. [1], Oklander T. [1], Shevchenko V. [9], Yermak, S. [2]. Leading specialists of well-known international and national companies ("Cable.co.uk" [6], "Dragon Capital" [12], "GfK" [5], "Info Sapiens" [11], "Kantar" [4], "Mlab" [7], "Picodi" [3]) focus their attention on the digital permanent transformations in the external environment.

Highlighting the previously unresolved parts of the general problem to which the article is devoted. For online retailers it is important to reactively transform the digital business in accordance with changing market demands, needs and preferences of online buyers, and take into account the priority competitors actions on the Internet. 
At the same time, it should be noted that the digitalization trend is contributing to reactive changes in the generally accepted behavior and preferences of online buyers. Considering the above, online retailers should correctly identify factors that influence online buyers' behavior and preferences to catalyze the positive development of digital business. In addition, in the context of digitalization, online retailers need to minimize the negative impact of the marketing environment factors, possibly due to a clear determination of the accents of the progressive and sustainable digital business development. The fragmentation of these problems study leads to further research.

Formulation of the purpose of the article (statement of the problem). The purposes of the study are to determine and interpret driver-factors of the digital business development, as well as to provide suggestions about accents of its progressive persistent development based on the results of a study of the background and a retrospective analysis of successful experience of DIY retailers in Ukraine.

Statement of the main material of the research with full justification of the scientific results obtained. The successful conduct and development of the retailers' digital business based primarily on their ability to correctly implement the marketing communication policy. It is mainly aimed at increasing of the online store traffic by generating relevant content, as well as focusing on creating a positive image in the Internet to maximize the online buyers' attraction and the achievement of the sales desired level. That is why it is advisable for retailers to monitor online buyers' requests, needs, and preferences. This emphasizes the importance of developing and detailed analysis of the profile of a typical Ukrainian online buyer, as well as the importance of systematic monitoring of all its changes.

According to [3], in 2018 in Ukraine, $46 \%$ of buyers in online stores were aged 25 to 34 years. Also the share of Ukrainian online buyers of goods in online stores aged 35-44 years was significant and amounted to $23 \%$. The lowest number of online purchases in Ukrainian online stores in 2018 was carried out by buyers over the age of 65 .

In 2019 according to a "GfK" study [5], the age range of an average Ukrainian online buyer is 26-35 years. Moreover, his average income increased by $8 \%$ compared with 2018 and amounted to about $5600 \mathrm{UAH}$, which is $1700 \mathrm{UAH}$ more than an offline buyer. Such age limits of Ukrainian online buyers in 2019 are determined by the specifics of the Internet audience, including their knowledge and skills for online shopping in online stores, as well as the level of prices for goods and / or services and purchasing power. In particular, the Purchasing power index in 2014-2019 decreased by 0.042 from 1.121 to 1.079 (Table 1).

Table 1 - Consumer price and purchasing power indexes in 2014-2019 (to previous year)

\begin{tabular}{|c|c|c|c|c|c|c|}
\hline Index & $2014^{1}$ & $2015^{2}$ & $2016^{2}$ & $2017^{2}$ & $\mathbf{2 0 1 8}^{2}$ & $2019^{2}$ \\
\hline Consumer price index & 1,121 & 1,487 & 1,139 & 1,144 & 1,109 & 1,079 \\
\hline Purchasing power index & 0,892 & 0,672 & 0,878 & 0,874 & 0,902 & 0,927 \\
\hline
\end{tabular}

Notes. ${ }^{1}$ - Data exclude the temporarily occupied territory of the Autonomous Republic of Crimea, the city of Sevastopol. ${ }^{2}$ - Data exclude the temporarily occupied territory of the Autonomous Republic of Crimea, the city of Sevastopol and a part of temporarily occupied territories in the Donetska and Luhanska oblast.

Source: calculated and composed by the author according to [13]

Table 1 indicates the $7.9 \%$ increase in the total price level of goods and services that Ukrainians buy for personal consumption, as well as the decrease in the volume of goods and services that Ukrainians could purchase for the same amount of money in 2019 compared to 
2018. Regarding the Consumer price index, it should be noted the downward trend starting from 2017. In 2018 and 2019, the Consumer price index was equal 0.035 and 0.065 , respectively. These indexes changes that are analyzed in the article allow to conclude about the negative impact of price increases taking into account the current income level of the population in Ukraine and the ability of the population to make purchases, including in online stores.

At the same time, with such Consumer price and Purchasing power indexes, according to the calculations based on data [5; 12], the Consumer confidence index in Ukraine had a positive trend since 2016. So, the average value of the Consumer confidence index in Ukraine in 2014 was 60.7, and in 2015 - 46.0, which is 5.4 and 12.3 less than in 2016 and 2017, respectively. In 2019, this index was 83.0, which is 37.0 more than in 2015 and 22.5 more compared to 2018. Since 2016, this index indicates a positive assessment of consumer market trends, as well as positive changes in consumer demand and its constant increase (Figure 1).

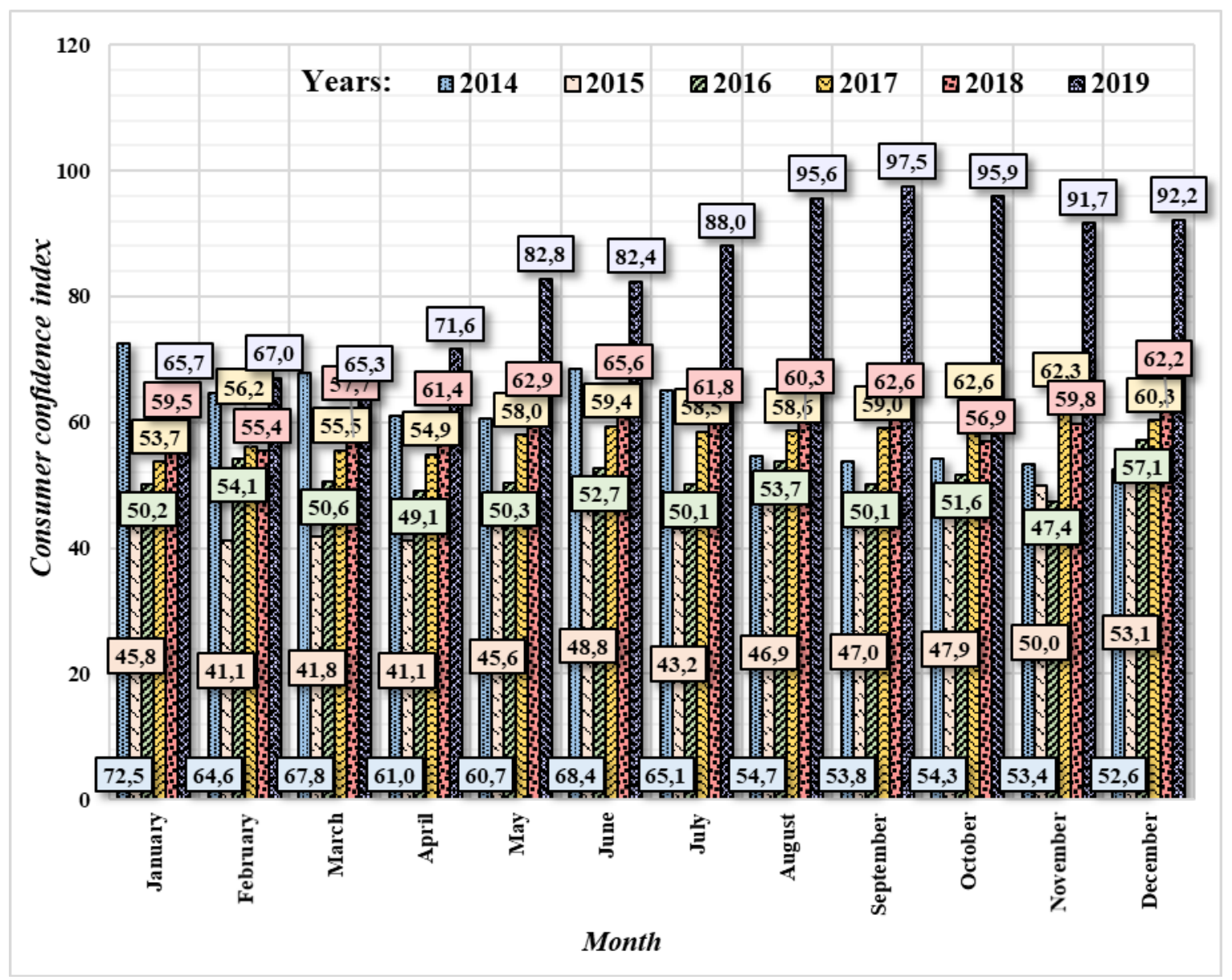

Figure 1 - The Consumer confidence index in Ukraine in 2014-2019 Source: composed by the author according to $[5 ; 12]$

According to the Figure 1, the Consumer confidence index in Ukraine in January 2019 was 65.7 due to optimistic expectations of consumers from the results of the presidential election, as well as wage growth in December 2018 [14] (The results of the "Info Sapiens" research [11] with the "Dragon Capital" support [12]). The highest value of the Consumer confidence index in Ukraine in 2018 was in June and May, they were 65.6 and 62.9, respectively. As for 2019, in April and May, the Consumer confidence index in Ukraine was 
71.6 and 82.8, respectively. These indexes are significantly higher than the corresponding values in 2016-2018, but are not maximum in 2019.

It should also be emphasized that since April 2019, the index values have already exceeded its highest values in 2014 (June, March). This represents the willingness and ability of buyers to make large purchases in 2019. From September 2019 to the end of December 2019, there was a gradual decrease in the Consumer confidence index by 5.3, from the maximum value of the index for the year -97.5 to 92.2 . These changes have not significantly affected the ability of buyers to make large purchases.

According to "Kantar" experts [4], since 2018, it has been a growth in the mobile-centric Ukrainian Internet audience. 16.7 million Ukrainians aged 12-70 years used mobile devices and/or gadgets to access the Internet in 2018, which is $15.5 \%$ more than in 2017. In general, in Ukraine, the proportion of users who access the Internet through a desktop is gradually decreasing, so in 2018 their share was $82 \%$, which is $7 \%$ less compared to 2017 . This trend is due to a significant increase of smartphones in the Ukrainian market, which could also be noted in the previous few years, as well as the widespread use of $3 \mathrm{G}$ and $4 \mathrm{G}$ networks. The average time spent by a Ukrainian Internet user on the Internet is 5.5 hours per day, which is 0.6 hours more than the average European person and 0.5 hours more than Internet users in the world [15].

It is important to note that the "Kantar" study [4] found that in 2018 potential online buyers spent $80 \%$ of their time on using mobile apps to search for product information (39\%), watch videos (36\%) and make online purchases $(25 \%)$. In 2018, the largest percentage of the Ukrainian Internet audience that used mobile applications for online shopping was in the age group of 26-35 years (35\%). Also, Internet users aged 16-25 and 36-45 years actively made purchases online through mobile applications, their percentages were $34 \%$ and $32 \%$.

So, according to the above, Ukrainian online retailers should consider Internet users as a perspective target audience (potential online buyers) for the dynamic development of their digital business. In addition, despite the fact that a certain part of the Internet audience in Ukraine began to use mobile devices in $2019,50 \%$ and $49 \%$ of online buyers made purchases of goods and / or ordered services on the Internet using laptops and desktops, respectively, $44 \%$ used smartphones, and only $11 \%$ used tablets [9]. This indicates a low level of tablets use for online shopping among Ukrainian buyers.

The successful communication with online buyers in the online store and through mobile applications is possible only if they have access to the fast Internet. According to the international company "Cable.co.uk" [6], which conducted research with "Mlab" [7] in order to identify the average speed of the Internet and compile an appropriate rating of countries, in 2019 Ukraine took 81 place among 207 countries, losing 23 positions compared to 2018 (Figure2).

According to Figure 2, in 2019 the fastest Internet in Europe had Sweden, Denmark, Netherlands and Switzerland. The only country that showed an increase in the rating for Internet speed in 2019 was Belarus. It increased by positions and took 57th place. Also, in 2018, the average Internet speed in Ukraine was 11.28 megabits per second, which was higher in Turkey, Belarus, Georgia and Monaco. Regarding the indicators of 2017, Ukraine took 54th place in the world in average Internet speed of 8.18 megabits per second. 


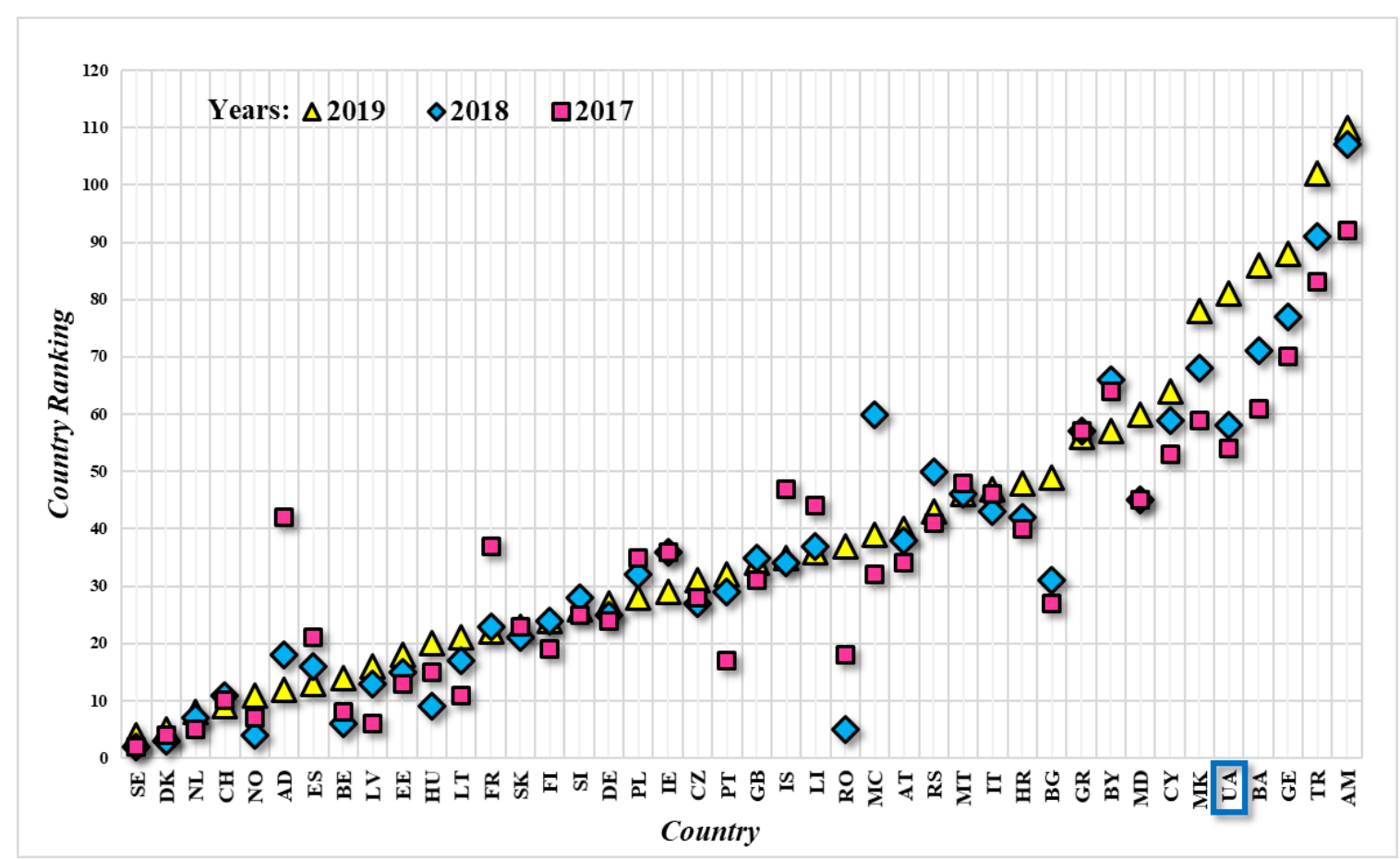

Figure 2 - Rating of European countries by Internet speed in 2017-2019

Notes. AD - Andorra, AM - Armenia, AT - Austria, BA - Bosnia and Herzegovina, BE -Belgium, BG - Bulgaria, BY - Belarus, CH - Switzerland, CY - Cyprus, CZ - Czechia, DE - Germany, DK - Denmark, EE Estonia, ES - Spain, FI - Finland, FR - France, GB - United Kingdom, GE - Georgia, GR - Greece, HR - Croatia, HU - Hungary, IE - Ireland, IS - Iceland, IT - Italy, LI - Liechtenstein, LT - Lithuania, LV - Latvia, MC Monaco, MD - Republic of Moldova, MK - North Macedonia, MT - Malta, NL - Netherlands, NO - Norway, PL - Poland, PT - Portugal, RO - Romania, RS - Serbia, SE - Sweden, SI - Slovenia, SK - Slovakia, TR Turkey, UA - Ukraine.

Source: composed by the author according to [15]

Thus, the study of the digital business background allows the author to conclude that, in order to expand the boundaries of the target audience and increase the level of regular online buyers' satisfaction, Ukrainian retailers need to systematically take correct management decisions to implement relevant marketing tools for promoting their online store. Such solutions are able to improve interaction with online buyers and determine the implementation of the online store optimization and certain mobile applications in accordance with the varied requests, needs and preferences of online buyers. In particular, reduce the loading time of relevant web pages and/or push messages, taking into account the speed of the Internet.

As part of identification the features of the digital business, as well as conducting a retrospective analysis, in order to identify the factors that determine the digitalization and transformation of business processes and, as a result, affect its dynamic development, in the article the author explores a cluster of retailers in the DIY segment, performing simultaneously offline and online trading (the cluster formation process is described in [16]). According to analysts [4-5; 10-12], the segment of Ukrainian DIY retail is still perspective, because it is not yet saturated, and the demand for enterprise goods is quite stable. It should be noted that the DIY retail format is wide, in connection with which two categories of stores can be distinguished, namely [17]:

1) retailers offering construction tools and professional repair products ("hard" DIY);

2) retailers specializing in goods for interior and home improvement ("soft" DIY). 
The product portfolio of two categories of DIY retailers allows them to successfully initiate the creation of new trading concepts, where different product groups are presented simultaneously.

Based on the results of study of different aspects of the Ukrainian DIY retailers' activities it is established that in the process of digital business developing the certain changes in strategies are tracked at various hierarchical levels and the modifications of business models are provided the positive online buyers experience. The development of the Ukrainian DIY retailers' digital business at the initial stage needed attention to develop an adaptive design of online stores with an acceptable and understandable interface for the online buyer, as well as visual design, which was based on the categorization of goods taking into account the needs and requirements of online buyers. Moreover, it is determined that the active development of the digital business in the DIY retail segment is facilitated by a clear focus on increasing the level of online buyers' trust, as well as improving and providing high-quality services and delivery, for which retailers should improve their own networks and increase the number of methods for delivering goods.

The Table 2 shows the traffic of five online stores Ukrainian DIY retailers in 2019 (according to the [18]). These retailers for a fairly short period of time quickly developed their digital business and did not lose their offline market share.

Table 2 - DIY Retailers' Traffic in 2019

\begin{tabular}{|c|c|c|c|c|c|}
\hline \multirow{2}{*}{ Date } & \multicolumn{5}{|c|}{ Total Visits of Online Stores, millions } \\
\cline { 2 - 6 } & Nov a Liniya & E picentr K & Leroy M erlin & Stil i stilecz' & JY SK \\
\hline $\mathbf{0 1 . 0 1 . 2 0 1 9}$ & 0,86 & 6,20 & 0,35 & 0,18 & 0,55 \\
\hline $\mathbf{0 1 . 0 2 . 2 0 1 9}$ & 0,67 & 5,90 & 0,25 & 0,16 & 0,42 \\
\hline $\mathbf{0 1 . 0 3 . 2 0 1 9}$ & 0,83 & 6,35 & 0,27 & 0,16 & 0,50 \\
\hline $\mathbf{0 1 . 0 4 . 2 0 1 9}$ & 0,75 & 5,90 & 0,52 & 0,12 & 0,48 \\
\hline $\mathbf{0 1 . 0 5 . 2 0 1 9}$ & 1,00 & 6,25 & 0,32 & 0,13 & 0,38 \\
\hline $\mathbf{0 1 . 0 6 . 2 0 1 9}$ & 0,87 & 6,65 & 0,32 & 0,14 & 0,46 \\
\hline $\mathbf{0 1 . 0 7 . 2 0 1 9}$ & 0,80 & 6,70 & 0,31 & 0,15 & 0,52 \\
\hline $\mathbf{0 1 . 0 8 . 2 0 1 9}$ & 0,77 & 6,95 & 0,32 & 0,18 & 0,56 \\
\hline $\mathbf{0 1 . 0 9 . 2 0 1 9}$ & 0,63 & 6,41 & 0,28 & 0,17 & 0,54 \\
\hline $\mathbf{0 1 . 1 0 . 2 0 1 9}$ & 0,57 & 6,42 & 0,27 & 0,16 & 0,58 \\
\hline $\mathbf{0 1 . 1 1 . 2 0 1 9}$ & 0,68 & 7,27 & 0,37 & 0,18 & 0,88 \\
\hline $\mathbf{0 1 . 1 2 . 2 0 1 9}$ & 0,60 & 7,90 & 0,35 & 0,17 & 1,25 \\
\hline
\end{tabular}

Source: composed by the author according to [18]

According to the Table 2, the most intense traffic in 2019 among the studied DIY retailers had the "Epicentr K". The number of its visits in December 2019 amounted to 7.90 million, which is significantly more compared to other retailers.

It is important to note that the number of visits of "Epicentr K" online store is determined by using the "Similar Web" service [18] taking into account the fact that 21.12.2019 the domain https://27.ua/ was changed to https://epicentrk.ua/. So, only in May 2019 in the "Nova Liniya" online store, the traffic was reached 1.00 million visits, and 1.25 million visits were recorded in the "JYSK" online store in December 2019. During the year, in all other online stores, with the exception of the above, the number of visits was in the range from 0.12 to 0.88 million. It should be emphasized, that such traffic is quite high, taking into account the specifics of the 
DIY segment in Ukraine, as well as the coverage of each individual retailer in the regions where goods are sold and delivered online.

Based on the results of the comparative analysis of the Ukrainian retailers' online stores traffic and diagnostics of the digital business effectiveness, the driver-factors of digital business development are determined and interpreted, which are recommended to be used as part of the measures implementation to achieve the general goal.

1. Focus DIY retail efforts on working with call center staff who provide the requested information to online buyers and inform them of existing promotional offers. Retailers should systematically implement a set of measures aimed at increasing the level of staff competence.

2. Using a CRM-system, which contributes to a better understanding of the actions of online buyers in the online store and allows retailers to obtain the necessary analytical information.

3. The development of expert online media tools, together with the active management of SMM channels, that allows DIY retailers to quickly increase the level of awareness of online buyers about their current activities in the Internet and gain some popularity among them. This is the foundation for substantiating personalized offers, as well as the opportunity to understand the demanding online buyers and offer the goods they need at the right time.

4. Creation by online retailers in the DIY segment of professional photo products that will be posted on the site and help to interest the online buyer, directly affecting his decision when ordering online.

5. Improving the service component of DIY retailers on the Internet. Nowadays online retailers provide a full range of services - advice on choosing a product, delivering goods and providing additional related services to online buyers. At the beginning of the formation and development of digital business, the main tasks of DIY retailers were to find suppliers, establish contacts with them and resolve the matrix of goods presented in the online store. Now, as specified in [8], the range of goods in most online stores DIY-retailers is much lower than in retail offline stores. However, in a relatively short period of time, the online format will be the beginning of growth for DIY segment retailers, because this is where they will be able to present a much wider range than in offline stores. Thus, in general, it can be stated a gradual increase in online sales by DIY retailers, as well as an increase in their market share in Ukraine.

The existence of a directly proportional relationship between the success of an online retailer and the degree to which the inquiries, needs and preferences of online buyers are met through an optimally developed product range that includes goods, which are valuable from their point of view. In the case of generating additional goods value for online buyers, the retailers in the DIY segment can earn more income from the sale by setting higher prices compared to competitors in the market.

Considering the above, the largest Ukrainian DIY-retailers are trying:

- timely and efficiently solve the current issues (if they occur);

- as quickly as possible to meet the changing varied demands, needs and preferences of online buyers with high-quality goods and services;

- make the best use of available analytical data.

These in the long run leads to the formation of a "seamless" experience of online buyers. The ability of online retailers in the DIY segment to compile algorithms for buyers to obtain a positive "seamless" omni channel experience in the Internet further promotes the online trust of these buyers.

The analytical research and retrospective analysis of the successful online experience of DIY retailers in Ukraine allowed the author to suggested the accents of the progressive and sustainable digital business development, which guarantee rapid scaling in the terms of intense competition and strengthen the competitive position of retailers in the market: 
1) an increase in the number of commodity items in the online store range;

2) the implementation of measures aimed at improving the delivery system of goods to online buyers, expanding geographical boundaries and increasing the number of channels and delivery methods;

3) the development and realization of programs of the positive "seamless" omni channel online buyer's experience formation; market).

4) digital businesses scaling up (increasing the geographical coverage of the national

Conclusions from this research and prospects for further developments in this area. The features of the mobile-centric Ukrainian Internet audience are identified and factors influencing their behavior are defined. It is argued that the active development of the digital business in the DIY retail segment is facilitated by a clear focus on increasing the level of online buyers' trust, as well as improving and providing high-quality services. The digital business development driver-factors are interpreted and determined on the basis of research and comparative analysis of the activities of the DIY retailers, aimed at increasing the online buyers' satisfaction level. These driver-factors are recommended to be used as part of the measures implementation to achieve the general goal. The analytical study and a retrospective analysis of the successful online experience of DIY retailers in Ukraine made it possible to offer accents of the progressive and sustainable digital business development, which guarantee rapid scaling in the terms of intense competition and strengthen the competitive position of retailers.

1. Oklander, M. A., Oklander T. O. (2017). Sehmentuvannia i komunikatsii v tsyfrovomu marketynhu [Segmentation and communication in digital marketing]. Marketing and management of innovations, no. 3, pp. 69-78.

2. Yermak, S. (2017). Problems of innovative activity development at food industry enterprises of Ukraine. Journal of Hygienic Engineering and Design, no. 21, pp. 96-102. Available at: http://www.jhed.mk/filemanager/JHED\%20Vol.\%2021/03.\%20FPP/09.\%20Full\%20paper\%20-

\%20Svitlana\%20Yermak.pdf (accessed 01 December 2019).

3. Picodi. (2019). Available at: https://www.picodi.com/ua/ (accessed 12 December 2019).

4. Kantar Ukraine. (2020). Available at: https://tns-ua.com/ (accessed 23 December 2019).

5. GfK. (2018). Available at: http://www.gfk.com/ (accessed 15 December 2019).

6. Cable.co.uk. (2019). Available at: https://www.cable.co.uk/ (accessed 26 November 2019).

7. Mlab. (2019). Available at: https://mlab.com/ (accessed 26 November 2019).

8. Lukianchenko, O. (2018). Za dva roky v lidery rynku: yak Epitsentr naroshchuie prodazhi mebliv [In two years in market leaders: how Epicenter increases furniture sales]. Retailers Association of Ukraine. Available at: https://rau.ua/dosvid/epitsentr-prodazhi-mebeli/ (in Ukrainian) (accessed 26 November 2019).

9. Shevchenko, V. (2020). Yak ukraintsi zdiisniuiut pokupky onlain [How Ukrainians make purchases online]. Na chasi. Available at: https://nachasi.com/2020/02/21/reddit-kyiv/ (accessed 01 December 2019).

10. Retail Association of Ukraine. (2020). Available at: https://rau.ua/ (accessed 12 December 2019).

11. Info Sapiens. (2019). Available at: https://sapiens.com.ua/ (accessed 23 December 2019).

12. Dragon Capital. (2019). Available at: https://dragon-capital.com/ (accessed 15 December 2019).

13. State Statistics Service of Ukraine. (2020). Indeksy spozhyvchykh tsin na tovary ta posluhy u 20022019 rr. [Consumer price indices for goods and services in 2002-2019]. Available at: http://www.ukrstat.gov.ua/operativ/operativ2008/ct/cn_rik/icsR/iscR_u/isc_tp_rik_u.htm (accessed 23 December 2019).

14. State Statistics Service of Ukraine. (2020). Oplata pratsi ta sotsialno-trudovi vidnosyny [Remuneration and social and labor relations]. Available at: http://www.ukrstat.gov.ua (accessed 23 December 2019). 
15. Worldwide broadband speed league. (2019). Available at: https://s3-eu-west1.amazonaws.com/assets.cable.co.uk/broadband-speedtest/worldwide-broadband-speed-league-2019data.xlsx (accessed 26 November 2019).

16. Natorina, A. (2018). The marketing commodity policy of online-retailers: characterization and trajectories of development. Scientific journal "Business Inform", no. 9, pp. 272-277. Available at: http://oaji.net/articles/2019/727-1547028786.pdf (accessed 23 December 2019).

17. Natorina, A. (2018). Online retailers' management system of marketing commodity policy. Economic Annals-XXI, no. 174 (9-10), pp. 69-72. Available at: http://soskin.info/userfiles/file/Economic-Annals-pdf/DOI/ea-V174-11.pdf (in English) (accessed 23 December 2019).

18. SimilarWeb. (2020). Available at: https://www.similarweb.com (accessed 26 November 2019).

Наторіна Альона Олександрівна, кандидат економічних наук, завідувач кафедри міжнародної економіки, обліку та фінансів Міжнародного науково-технічного університету імені академіка Юрія Бугая (Київ, Украӥна).

Цифровий бізнес в Україні: бекграунд та ретроспектива.

Грунтуючись на результатах аналітичного дослідження бекграунду иифрового бізнесу встановлено, щьо для розширення меж иільової аудиторії та підвищення рівня задоволеності онлайн-покупиів, ритейлерам необхідно впроваджувати релевантний маркетинговий інструментарій, оптимізувати роботу Інтернет-магазину $i$ мобільних додатків. $3 а$ результатами компаративного аналізу діяльності Інтернет-магазинів украӥнських DIYритейлерів детерміновано та інтерпретовано драйвер-чинники розвитку цифрового бізнесу, що рекомендовано використовувати у рамках реалізаиї заходів для досягнення генеральної мети. Проведено ретроспективний аналіз досвіду онлайн-діяльності DIY-ритейлерів в Украӥні та запропоновано акиенти прогресивного персистентного розвитку цииррового бізнесу, щзо гарантують швидке масштабування в умовах інтенсивної конкурениї та посилюють конкурентні позиції ритейлерів.

Ключові слова: DIY-ритейл, акценти прогресивного персистентного розвитку цифрового бізнесу, драйвер-чинники розвитку цифрового бізнесу, Інтернет-магазин, цифровий бізнес.

Received to the editor January 9, 2020 